\title{
AZ ÁLLATTARTÁS TERÜLETI SAJÁTOSSÁGAI MAGYARORSZÁGON
}

(The regional features of animal husbandry in Hungary)

\author{
SZÉLES GYULA
}

\section{A jelenlegi helyzet bemutatása}

Az állattenyésztés rendkivül sokoldalúan kapcsolódik egy ország nemzetgazdaságához. Megítélhető ez egyfelöl az inputok, a transzformáció bemeneteli oldala, másfelöl a kibocsátások, a fontos és nélkülözhetetlen termékei alapján. Az elsóvel kapcsolatban azt kell kiemelni, hogy az állattenyésztés útján hasznosíthatók olyan fontos nemzeti erőforrások, mint a gyepes területek, a szántóföldön elóállított takarmányok és melléktermékek, az állattartáshoz szükséges épületek (istállók, ólak) és ezek müködését kiszolgáló infrastruktúra, a munkaerő stb. Az állattenyésztés kibocsátásaira épül a hazai élelmiszerellátás, továbbá a kủlgazdaság útján értékesíthető árualapok tömege. Az elmúlt években, a mezőgazdasági és élelmiszeripari termékek exportjának visszaesése ellenére méretét és arányát tekintve is jelentősnek kell minösíteni a tej-, hús- és baromfiipari, valamint az élóállatok és egyéb állati eredetủ kibocsátásokat. Ere utaló adatok láthatók az 1. táblázaton, amely 1990-95. évek összes mezögazdasági és élelmiszeripari termékek exportját, valamint az állattenyésztés bázisán megtermelt áruk részesedését mutatja. $\mathrm{Az}$ adatok az állati eredetü termékek részesedésének jelentős visszaesésére ut:lnak, amelynek legfőbb oka a termelés méretét alapvetően meghatározó állatállomány drasztikus csökkenése. A föbb exportcikkeket tekintve a kivitelben bekövetkezett kedvezőtlen fordulat legerősebben húságazat értékesítésének visszaesésében mutatkozik meg. 1992töl mind az élö, mind a feldolgozott formában kivitt sertés- és marhahús volumene, exportjának zuhanása rendkívül nagy mértékü. 1993-ban, az 1991-92. évi eladások megközelítően egyharmadára estek vissza. Ezt a folyamatot a már említett csökkenö állatállomány kapcsán bekövetkezỏ mérséklődő árualap mellett még állategészségügyi problémák, az EU húsembargója (1993. évi bárány exportnál jelentkezỏ diszkrimináció) is súlyosbítottak. Erre a rendkívül kedvezőtlen jelenségre azért is kell kiemelt figyelmet fordítani, mert a magyar agrárium két meghatározó tartópillérre épül: az egyik a gabonatermelés, a másik ehhez szervesen kapcsolódó húsvertikum. 


\section{TÁBLÁZAT}

Az élelmiszergazdaság fóbb szakágazatai devizabevételeinek szerkezete 1991-95. években

(USA \$-ban kifejezett devizatömeg \%-os megoszlásban)

(The structure of the foreign currency incomes of food production by major sectors in 1991-1995 [Breakdown of foreign currency expressed in USD])

\begin{tabular}{|l|r|r|r|r|r|}
\hline \multicolumn{1}{|c|}{ Megnevezés } & 1991 & 1992 & 1993 & 1994 & 1995 \\
\hline Gabonaágazat & 12 & 25 & 8 & 11 & 32 \\
Nơvényolaj vertikum & 8 & 9 & 10 & 10 & 6 \\
Gyămölcsvertikum & 12 & 10 & 15 & 16 & 7 \\
Zöldségvertikum & 11 & 11 & 13 & 16 & 13 \\
Szölö-bor vertikum & 2 & 3 & 7 & 5 & 5 \\
Állattenyésztés & 55 & 42 & 47 & 42 & 37 \\
- sertés-vertikum & 21 & 12 & 14 & 11 & 10 \\
- baromfivertikum & 20 & 17 & 20 & 20 & 17 \\
- szarvasmarha vertikum & 11 & 10 & 9 & 8 & 6 \\
- juh ágazat & 2 & 3 & 4 & 3 & 4 \\
\hline
\end{tabular}

Forrás: Harza et. al. AKII. 1995

Ez utóbbi kiépítése érdekében a nemzetgazdaság rendkivül erőfeszítéseket tett, jelentỏs gazdasági áldozatot hozott, viszont 1994-96. években, éppen a hazai állatállomány feltartóztathatatlan leépülése miatt alapanyag-hiánnyal küszködik. Ez a körülmény kedvezőtlenül befolyásolja a nagy értékủ termelö-berendezések kihasználását, megnövekednek az állandó költségek, amelynek következtében romlik a hatékonyság, a húsipari termékek nemzetközi versenyképessége.

A tej- és tejtermékek exportvolumene tejegyenértékben kifejezve ugyancsak csökkent, amely természetesen együtt járt az árbevétel látványos visszaesésével. Ugyanakkor egy rendkivül dinamikusan növekvő tejtermékimport figyelhető meg és szembetünő, hogy 1992 és 1993. években, az importból származó tejtermékek értéke jelentősen meghaladta az exportált áruk árbevételének tömegét. Ez a tendencia nemzetgazdasági szempontból is kedvezőtlen, súlyos gondokat vet fel, amelyek közül a következöket kell kiemelni.

Belföldön, hazai eróforrások (mezögazdasági terület, munkaerö, állatállomány stb.) felhasználásával is megtermelhetö termékeket külföldröl hozunk be, feleslegesen terhelve ezzel az ország nemzetközi fizetési mérlegét.

$\mathrm{Az}$ import, piaczavaró hatást fejt ki, fogyasztói árfelhajtó sajátossággal jellemezhetō, a tehetös rétegek vásárlóerejét leköti.

Fokozza a nemzetgazdaság, ezen belúl az élelmiszeripar nehézségeit azzal, hogy egyfelöl a termelési kapacitások kedvezőtlen kihasználása révén növeli az állandó költséget, másfelỏl jelentős munkanélküliséget gerjeszt.

A magyar élelmiszergazdaság nem rendelkezik megfelelő importvédelmi rendszerrel, az importengedélyezési gyakorlatunk GATT szempontból kifogásolható.

A nemzetgazdaság szempontjából kétségtelenül jelentős állati eredetủ termékek exportja mellett kiemelt feladat a belfơldi ellátáshoz szükséges árualapok biztosítása. Erre azért is kell a figyelmet felhívni, mert a társadalmi köztudatban, de néha még a szakmai közvéleményben is mindinkább elterjedöben vannak olyan nézetek, hogy a magyar élelmiszergazdaság válsághelyzetének, a tartós recessziónak legfőbb okozója a tradicionális külpiacainak (KGST és az egykori Szovjetunió, Kelet-Németország szétesése stb.) 
elvesztése. Kevés szó esik arról a sokkal fontosabb tényező-komplexumról, amely a belföldi, a hazai fogyasztói felvevő piacok, beszükülésével van összefüggésben. Ennek megítélése kapcsán abból az alapvető premisszából kell kiindulni, hogy minden országban a mezőgazdasági termelés legfontosabb feladata a saját lakossága élelmiszerszükségletének megteremtése, a belföldi fogyasztás árualapjának biztosítása. Ez volt a jellemző évtizedeken át a magyar élelmiszergazdaságra is, mivel az agrártermelésben lekötött erőforrások (termőfỏld, állatállomány stb.) mintegy $65-70 \%$-a a belső ellátást, a hazai élelmiszerszükséglet előallítását szolgálta. Ebböl következik, hogy élelmiszergazdaságunk válságának, az elhúzódó recesziónak legföbb okozója belső piacvesztés, amely alapvetően összefüggésben van a fizetöképes kereslet jelentős csökkenése következtében beálló eröteljes élelmiszer-fogyasztás visszaesésével. Az élelmiszer- és tápanyagfogyasztás változása kapcsán ez jól nyomon követhetö, amelyröl részletesen a 2. táblázat adatai nyújtanak részletes információt. Szembetünő néhány, föleg állati eredetủ alapélelmiszer-fogyasztásának változása. A hús- és húskészítmények tekintetében $15-$ $20 \%$-os visszaesés tapasztalható, amely föleg a sertés- és baromfihúsra vonatkozik. Táplálkozásbiológiai szempontból a baromfihús fogyasztás csökkenése jelenthet gondokat, ugyanis 1986-88. években 31-32 kg/fö, 1993-94. években 18-19 kg/fö volt a fogyasztási színvonal. Jóval nagyobb és összetettebb egészségügyi konzekvenciákkal jár a tej- és tejtermékek fogyasztásának 30-35\%-os visszaszorulása. Ennek megitélése kapcsán egyfelől abból kell kiindulni, hogy a táplálkozástudomány müvelöi szerint az emberi szervezet napi 50-55 g állati eredetú fehérje szükségletét legkisebb költséggel a tejés tejtermékek fogyasztásával lehet kielégíteni. Másfelöl egyre szélesebb körben terjed az utóbbi években szinte népbetegséggé váló csontritkulás (oszteoporózis), amely különösen a nők számára lehet veszélyes, mivel a szoptatás során a szervezetböl kiürủlő kalciumot, amennyiben nem pótolják, a csontokból kerül kivonásra. Az emberi szervezet számára a legfontosabb Ca forrásnak a tejet és ennek termékeit tekintjük, így a drasztikus fogyasztás-csökkenés már-már népünk egészségi állapotát veszélyezteti. A zsiradékok fogyasztásának növekvő trendjét is aggodalommal kell szemlélni, különösen ha figyelembe vesszük a napi energia felvétel ( $\mathrm{kJ} /$ nap) alakulását. Ezen változás mögött az húzódik meg, hogy a fogyasztók a csökkenö húsféléket, tejtermékeket és cereáliákat (liszt és rizs) az energiaszint-biztosításához, az olcsóbb zsiradékok felvételével pótolják. Az előzőekben részletesen kifejtett tényezők minden bizonnyal jelentősen hozzájárulnak népünk egészségi állapotának igen nagyfokú romlásához, a halálozási arányok ugrásszerủ megnövekedéséhez. Ennek illusztrálására az 3. táblózaton nemzetközi összehasonlításban mutatjuk be a halálozási arány alakulását hazánkban, amelyből megdöbbentő kép tárul elénk és mindenkinek el kell gondolkozni ezen, aki e nemzet jövöjéért felelősséget érez.

A hazai élelmiszerfogyasztás számottevő csökkenését igazolják az Agrárgazdasági Kutató és Informatikai Intézetben 1994-ben elvégzett számítások is, amely szerint az elmúlt időszakban évente 150 milliárd Ft-tal csökkent az élelmiszerek és élvezeti cikkek kereskedelmi forgalma. 


\section{TÁBLÁZAT}

Egy fớre vetitett élelmiszer- és tápanyagfogyasztás változása 1950-1994. években, $\mathrm{kg} / e ̉ v, d b / e ́ v e ́ s ~ k J / n a p$

(Change of food and nutriments consumption per person between 1950-1994, kg/year, pcs/year and kJ/day)

\begin{tabular}{|c|c|c|c|c|c|c|c|c|}
\hline Év & $\begin{array}{l}\text { Hús és húské- } \\
\text { szitmények, hal } \\
\mathrm{kg} / \mathrm{e} v\end{array}$ & $\begin{array}{c}\text { Tej és } \\
\text { tejterméke } \\
\mathbf{k} \\
\mathrm{kg} / \mathrm{e} v\end{array}$ & $\begin{array}{l}\text { Tojás } \\
\mathrm{db} / \mathrm{ev}\end{array}$ & $\begin{array}{c}\begin{array}{c}\text { Zsiradé- } \\
\text { kok }\end{array} \\
\text { kg/év }\end{array}$ & $\begin{array}{c}\text { Liszt és } \\
\text { rizs } \\
\text { kg/év }\end{array}$ & $\begin{array}{l}\text { Cukor } \\
\mathrm{kg} / \mathrm{év}\end{array}$ & $\begin{array}{c}\text { Burgonya } \\
\mathrm{kg} / \mathrm{e} v\end{array}$ & Tápanyag \\
\hline 1950 & 34,9 & 99,0 & 85 & 18,7 & 142,1 & 16,3 & 108,7 & 11317 \\
\hline 1960 & 49,1 & 114,0 & 160 & 23,5 & 136,1 & 26,6 & 97,6 & 12301 \\
\hline 1970 & 60,4 & 109,6 & 247 & 27,7 & 128,2 & 33,6 & 75,1 & 12971 \\
\hline 1975 & 71,2 & 126,6 & 274 & 29,1 & 122,2 & 39,4 & 66,8 & 13574 \\
\hline 1980 & 73,9 & 166,2 & 317 & 30,5 & 115,2 & 37,9 & 61,2 & 13486 \\
\hline 1985 & 81,3 & 199,1 & 328 & 34,1 & 113,0 & 35,5 & 54,5 & 13703 \\
\hline 1990 & 75,8 & 169,9 & 389 & 37,1 & 110,4 & 38,2 & 61,0 & 14164 \\
\hline 1994 & 69,5 & 141,1 & 340 & 38,4 & 92,0 & 34,5 & 58,7 & 12770 \\
\hline
\end{tabular}

Forrás: KSH kiadványok

\section{TÁBLÁZAT}

A halálozási arány nemzetközi alakulása (Changes of international mortality rates)

\begin{tabular}{|l|r|r|r|r|r|r|}
\hline \multirow{2}{*}{ Ország } & \multicolumn{7}{c|}{ 1000 lakosra jutó halálozások száma } \\
\cline { 2 - 7 } & 1970 & 1980 & 1990 & 1991 & 1992 & 1993 \\
\hline Ausztria & 13,2 & 12,2 & 10,6 & 10,6 & 10,5 & 10,3 \\
Belgium & 12,3 & 11,5 & 10,6 & 10,7 & 10,3 & 10,6 \\
Bulgária & 9,1 & 11,1 & 12,1 & 12,3 & 12,0 & 12,9 \\
Csehszlovákia & 11,6 & 12,2 & 11,7 & 11,5 & & \\
Egyesült Államok & 9,4 & 8,7 & 8,7 & 8,6 & 8,5 & 8,8 \\
Egyesult Királyság & 11,8 & 11,7 & 11,2 & 11,2 & 10,7 & \\
Finnország & 9,6 & 9,3 & 10,0 & 9,8 & 9,8 & 10,1 \\
Görögország & 8,4 & 9,1 & 9,3 & 9,3 & 9,5 & 9,4 \\
Lengyelország & 8,2 & 9,8 & 10,2 & 10,6 & 10,2 & 10,2 \\
Magyarország & 11,6 & 13,6 & 14,1 & 14,0 & 14,4 & 14,6 \\
Németország & & & 11,5 & 11,1 & 10,9 & 11,1 \\
Norvégia & 10,0 & 10,1 & 10,7 & 10,5 & 10,4 & 11,0 \\
Portugália & 10,8 & 9,7 & 10,4 & 9,7 & 10,3 & \\
Románia & 9,5 & 10,4 & 10,6 & 10,9 & 11,6 & 11,6 \\
Szlovénia & & & 9,3 & 9,7 & 9,6 & 10,1 \\
\hline
\end{tabular}

Forrás: Demográfiai Évkönyv, 1993 
Széles Gyula : Az állattartás területi sajátosságai Magyarországon

Tér és Társadalom 10. évf. 1996/4. 99-111. p.

\section{Az állatállomány változása és területi elhelyezkedésének sajătosságai}

Hazánk állatállományának 1985-95. években állatfajonkénti összetételét az 4 táblázat adatai mutatják. Megállapítható, hogy a vizsgált idószakban szarvasmarha- és juhállományunk több mint felére csökkent, ehhez közel esik a sertésállomány visszaesése is. Szembetủnó az is, hogy a felnött baromfilétszám több mint egyharmaddal csökkent, amely igen jelentós, mintegy 14 millióval kisebb létszámot takar. Külön figyelmet kell fordítani a reprodukció alapját képezó anyaállomány változására, amelynek jellemzó adatai a 5. táblázaton láthatók. Az elóző táblázaton bemutatott adatokkal ősszehasonlítva megállapítható, hogy az anyaállatok létszámának csökkenése kisebb mértékủ, továbbá ezek kibocsátásai, a tehén-tej és juhtej szinte napi árbevételt jelentenek, így enyhítenek a szorító likviditási gondokon. A táblázatból az is szembetúnik, hogy 1995-ben anyakocáknál megállt a több mint tíz éven át tartó és szinte minden állatfajra kiterjedó állománycsőkkenés, mivel a kocaállomány esetében 3 ezer egyedes növekedést regisztráltak.

\section{TẢBLÁZAT}

Az állatállomány változása Magyarországon 1985-95. években, március 31. adatok alapján, 1000 egyedben

[Transition of the number of livestock in Hungary in 1985-1995, by data of 31. March (in thousand)]

\begin{tabular}{|c|c|c|c|c|}
\hline Évek & Szarvasmarha & Sertés & Juh & Felnött baromfi \\
\hline 1985 & 1948 & 9168 & 2465 & 38376 \\
1990 & 1637 & 8457 & 1865 & 31121 \\
1991 & 1597 & 8588 & 2289 & 28912 \\
1992 & 1369 & 6175 & 2076 & 30353 \\
1993 & 1114 & 5813 & 1598 & 26542 \\
1994 & 984 & 5035 & 1237 & 24183 \\
1995 & 951 & 4669 & 1074 & 63,0 \\
\hline
\end{tabular}

Forrás: Állatállomány 1995. március 3 I-én. KSH Budapest

\section{TÁBLÁZAT}

Az anyaállomány változása Magyarországon 1985-95. években, a március 31. adatok alapján, 1000 egyedben

[Transition of the number of sucklers in Hungary in 1985-1995, by data of 31. March (in thousand)]

\begin{tabular}{|c|c|c|c|}
\hline Évek & Tehén & Anyakoca & Anyajuh \\
\hline 1985 & 709 & 693 & 1646 \\
1990 & 639 & 661 & 1313 \\
1991 & 612 & 596 & 1497 \\
1992 & 540 & 485 & 1430 \\
1993 & 482 & 449 & 1038 \\
1994 & 441 & 380 & 845 \\
1995 & 423 & 383 & 792 \\
\hline Index 1995=1985 & 59,7 & 55,3 & 48,1 \\
\hline
\end{tabular}

Forrás: Állatállomány 1995. március 31-én. KSH Budapest 
Az állatállomány változásának egész országunkra jellemzỏ átlagai mögött rejlö terùleti sajátosságok feltárása érdekében megvizsgáltuk megyénként és főbb tájanként is az állat-létszámadatokat, választ keresve a mozgásokat elöidéző ok-okozati összefüggésekre. Az értékelés során 1991. és 1995. években elvégzett állatállományi statisztikai felvételekre alapoztunk. Vizsgálataink a szarvasmarha, ezen belül a tehénállomány, valamint a sertés, ezen belül a kocaállomány változásának területi sajátosságaira terjedtek $\mathrm{ki}$. Az összes szarvasmarha- és tehénállomány megyénkénti és föbb tájankénti elhelyezkedését és 1991-95. években bekövetkezett változását a 6. táblázaton ismertetjük.

\section{TÁBLÁZAT}

A szarvasmarha és tehénállomány változása 1991-95. években, ezer egyed, illetve 1991. év indexében kifejezve, \%

(Transition of the number of cattle and cows in Hungary in 1985-1995, in thousand and in per cent of the 1991 values)

\begin{tabular}{|l|c|c|c|c|c|c|}
\hline \multirow{2}{*}{ Megyék } & \multicolumn{2}{|c|}{ Összes szarvasmarha } & Index & \multicolumn{2}{|c|}{ Ebböl tehén } & Index \\
\cline { 2 - 3 } & 1991 & 1995 & $\%$ & 1991 & 1995 & $\%$ \\
\hline Baranya & 73 & 43 & 59 & 27 & 17 & 63 \\
Fejér & 86 & 62 & 72 & 33 & 27 & 82 \\
Gyór-Moson-Sopron & 116 & 72 & 62 & 42 & 30 & 72 \\
Komárom-Esztergom & 33 & 20 & 61 & 12 & 8 & 67 \\
Somogy & 79 & 42 & 53 & 29 & 19 & 66 \\
Tolna & 77 & 50 & 65 & 26 & 20 & 77 \\
Vas & 82 & 55 & 67 & 31 & 23 & 74 \\
Veszprém & 78 & 54 & 69 & 29 & 22 & 76 \\
Zala & 66 & 34 & 52 & 25 & 16 & 64 \\
Dunántúl & 690 & 432 & 63 & 254 & 184 & 72 \\
Dél-Dunántúl & 295 & 169 & 57 & 107 & 72 & 67 \\
Bács-Kiskun & 105 & 59 & 56 & 44 & 29 & 66 \\
Békés & 102 & 62 & 61 & 38 & 26 & 68 \\
Csongrád & 87 & 54 & 62 & 33 & 25 & 76 \\
Hajdú-Bihar & 124 & 89 & 72 & 48 & 39 & 81 \\
Jász-Nagykun-Szolnok & 113 & 71 & 63 & 42 & 30 & 71 \\
Pest, Budapest & 98 & 55 & 56 & 40 & 26 & 65 \\
Szabolcs-Szatmár-Bereg & 113 & 47 & 42 & 44 & 23 & 52 \\
Alfóld & 742 & 437 & 59 & 289 & 198 & 69 \\
Borsod-Abaúj-Zemplén & 89 & 46 & 52 & 39 & 23 & 59 \\
Heves & 39 & 22 & 56 & 15 & 10 & 67 \\
Nógrád & 37 & 14 & 38 & 15 & 8 & 53 \\
Észak & 165 & 82 & 50 & 69 & 41 & 59 \\
Magyarország & 1597 & 951 & 60 & 612 & 423 & 69 \\
\hline
\end{tabular}

Forrás: Magyarország állałállománya 1991. március 31 -én., KSH Budapest 1992.

Állatállomány 1995, március 31. KSH Budapest 1995.

Szembetủnő a táblázatból, hogy az országos átlagnál Észak-Magyarországon (Borsod-Abaúj-Zemplén, Heves és Nógrád) jóval nagyobb a csökkenés, de a DunántúIon belül Dél-Dunántúl (Baranya, Somogy, Tolna és Zala) esetében is hasonló jelenség tapasztalható. Erre azért is fel kell figyelni, mert a marhatartás szempontjából ÉszakMagyarország a hazai átlagnál kedvezöbb ökológiai adottságokkal jellemezhető. Erre utal az, hogy míg országosan a mezögazdasági területböl a gyep 18\%-kal részesedik, 
addig az Észak-Magyarországon ez $27 \%$, ezen belül Borsod-Abaúj-Zemplén megyében $31 \%$. Az országos átlagnál kedvezöbb mind a csapadék abszolút mennyisége, mind havi megoszlás, amely a gyepek és a szántón megtermelt tömegtakarmányok terméshozama szempontjából fontos tényezönek tekinthető. A Dél-Dunántúli (Baranya, Somogy, Tolna, Zala) régióban a szarvasmarha és tehénállomány csökkenése azért is meglepő, mert olyan tradicionális és nagy múltú marhatartó tájakat érint, mint Somógyban a Kaposvölgye, továbbá a Baranya és Somogy megyék területén elhelyezkedő Zselicség, valamint Zalában a Gơcsej-Hetés és a Zala folyó vőlgye. Ezek bázisán teremtődőtt meg az 1970-es évek végén, és az 1980-as évek elején a dél-dunántúli régióban egy koncentrált tejipari feldolgozó kapacitás (Pécs, Kaposvár, Barcs, Marcali, Szekszárd, Zalaegerszeg) amelynek a délszláv háborús helyzet kirobbanásáig igen jelentős folyadék-tej és tejtermék-exportja volt az egykori Jugoszláviába. Említhetnénk még a valamikori virágzó horváth-szerb-szlovén bevásárlóturizmus áru-alap igényét, amelynek egyik fö keresleti iránya a tejtermékekhez, föleg a sajthoz kapcsolódott. Idöszakosan ugyan, de a nyári hónapokban fontos felvevö-piacot jelent a Nyugat és Dél-Balaton környékén elhelyezkedő üdülőhelyek ellátása is. A Dél-Dunántúlon a gazdasági adottságok összességében kedvezőek a szarvasmarha-tenyésztés, ezen belül a tehéntartás számára.

Az ökológiai adottságok a kérődzỏ állatfajok számára ugyancsak jobbak az országos átlagnál. Erre utal mindenek elött az, hogy míg országosan a gyep 18\%-kal részesedik a mezőgazdasági területből, addig ez Somogyban 18\%, ezen belül a Kaposvölgyében $28 \%$, a Zselicségben $30 \%$, Zalảban $27 \%$. A gyep- és a szántóföldi tömegtakarmányok hozama szempontjából fontos a csapadék mennyisége és tenyészidőbeli megoszlása, amely még az észak-magyarországi megyéknél is jóval kedvezőbb. Éghajlatán érződik a mediterrán jelleg, jellemző a kevésbé aszályra hajłó nyár, az 50 éves évi csapadékátlag $740 \mathrm{~mm}$. Az ökológiai és ökonómia tényezők optimális összhangjára utaló lehetőségeket kitünően mutatja a Dél-Baranyában mủködő Bolyi Mezőgazdasági Termelö és Kereskedelmi Részvénytársaság példája, ahol mår évek óta 2000 tehén átlagában egy tehénrẹ vetítve több mint 8000 liter tejet termelnek. Ez a kiemelkedő fajlagos hozam vetekszik az Észak-Amerikai Egyesullt Államok és Izrael legjobb tejtermelö tehenészeteinek termelési eredményeivel. A Dél-Dunántúlon kimutatott és a Dunántúl egészéhez, valamint az országos átlaghoz viszonyított összes szarvasmarhára jellemző nagymértékủ visszaesés valójában két megyére, Somogyra és Zalára vonatkozik, mivel a baranyai csökkenés megegyezik az Alfơldével és csupán egy százalékkal marad el a hazai értéktöl.

A 6. táblázat második részében bemutatott tehénállomány területi elhelyezkedése és 1991-95. években történt változása tekintetében kisebb a csökkenés mértéke, kiegyenlítettebb a helyzet a megyék és régiók között. A legnagyobb a tehénlétszám csökkenése Észak-Magyarországon, az Alföldön az országos átlaggal megegyezö, a Dunántúlon viszont kisebb, ezen belül a Dél-Dunántúlon is csak két százalékkal marad el a hazai átlagtól.

- A szarvasmarha-tenyésztés területi sajátosságainak feltárása érdekében megvizsgáltuk gazdasági szervezetenkénti megoszlását. Az értékelés során az általános mezögazdasági összeirásban megfigyelt gazdaságkategóriákat alkalmaztuk, ezek: mezógazdasági vállalatok és gazdasági társaságok, mezögazdasági szővetkezetek, egyéni gazdálkodók.

Az 1991-95. években az összes szarvasmarha és tehénállomány gazdasági szervezetenkénti megoszlásával kapcsolatban megállapitható, hogy 1991. évtől kezdődően mind az összes szarvasmarha, mind a tehénállomány tekintetében hasonló trendek érvényesülnek: a szövetkezeti gazdaságok részesedése számottevően csökkent, amíg a vállalatok és gazdasági társaságok szinte megegyezö mértékben növelték részesedésüket. 
A juhállomány tekintetében a gazdasági szervezetek kỏzötti strukturális változás még kifejezettebb. Ugyanis 1991. évben a juhállomány 10\%-át vállalatok és gazdasági társaságok, 49\%-át szövetkezetek, 41\%-át egyéni gazdálkodók tartották, viszont 1995-ben 7\%-ra csőkkent a vállalatok és gazdasági társaságok részesedése, 19\%-ra fogyott a szóvetkezeteké, míg 74\%-a egyéni gazdák tulajdonába került. Ez egyben azt is jelenti, hogy a juh kiszorult a nagyüzemekből és az egyéni gazdák meghatározó arányt képviselnek hazai juhtenyésztésünkben.

Megállapítható, hogy a szövetkezetekben mind az összes sertés, mind a kocaállomány évröl-évre szinte hasonló mértékben csökkent, de visszaesett az egyéni gazdasảgok részesedése is. Jelentősen növekedett a vállalatok és gazdasági társaságok részesedése az összes sertésbỏl és a kocaállományból is.

A szarvasmarha- és tehénállomány gazdaságkategóriák szerinti megye-soros vizsgálatát külön is elvégeztük, ahol 1991. évi általános mezỏgazdasági összeírás adatait használtuk fel. Az értékelés eredménye a 7. táblázaton látható.

\section{TÁBLÁZAT}

A szarvasmarha és tehénállomány gazdaságkategóriảk szerinti megoszlása 1991. március 31. adatok alapján,\%

(Breakdown of the number of cattle ad cows by economic organisations, by data of 31 . March 1991, in per cent)

\begin{tabular}{|l|c|c|c|c|c|c|}
\hline \multirow{2}{*}{ Megyék } & \multicolumn{3}{|c|}{ Összes szarvasmarha } & \multicolumn{3}{c|}{ Ebböl tehén } \\
\cline { 2 - 7 } & $\begin{array}{c}\text { Vállałatok } \\
\text { és gazdasági } \\
\text { társaságok }\end{array}$ & $\begin{array}{c}\text { Szövet- } \\
\text { kezetek }\end{array}$ & $\begin{array}{c}\text { Egyéni } \\
\text { gazdá!- } \\
\text { kodók }\end{array}$ & $\begin{array}{c}\text { Vállalatok } \\
\text { és gazdasági } \\
\text { társaságok }\end{array}$ & $\begin{array}{c}\text { Szövet- } \\
\text { kezetek }\end{array}$ & $\begin{array}{c}\text { Egyéni } \\
\text { gazdát- } \\
\text { kodók }\end{array}$ \\
\hline Baranya & 21 & 58 & 21 & 20 & 56 & 24 \\
Fejér & 35 & 56 & 9 & 36 & 54 & 10 \\
Gyór-M-Sopron & 17 & 63 & 20 & 17 & 61 & 22 \\
Komárom-Esztergom & 37 & 54 & 9 & 40 & 50 & 10 \\
Somogy & 25 & 58 & 17 & 24 & 56 & 20 \\
Tolna & 30 & 59 & 11 & 28 & 60 & 12 \\
Vas & 12 & 70 & 18 & 11 & 63 & 26 \\
Veszprém & 26 & 64 & 10 & 25 & 61 & 14 \\
Zala & 13 & 68 & 19 & 12 & 60 & 28 \\
Dunántút & 23 & 61 & 16 & 22 & 59 & 19 \\
Dél-Dunántút & 23 & 60 & 17 & 21 & 58 & 21 \\
Bács-Kiskun & 23 & 51 & 26 & 20 & 47 & 33 \\
Békés & 26 & 50 & 24 & 28 & 50 & 22 \\
Csongrád & 17 & 60 & 23 & 19 & 56 & 25 \\
Hajdú-Bihar & 14 & 56 & 30 & 15 & 49 & 36 \\
Jász-Nagykun-Szolnok & 21 & 60 & 19 & 21 & 57 & 22 \\
Pest, Budapest & 21 & 63 & 16 & 21 & 63 & 16 \\
Szabolcs-Szatmár-Bereg & 10 & 56 & 34 & 11 & 48 & 41 \\
Alfóld & 19 & 57 & 24 & 19 & 52 & 29 \\
Borsod-Abaúj-Zempléll & 18 & 54 & 28 & 16 & 50 & 34 \\
Heves & 10 & 71 & 19 & 9 & 69 & 22 \\
Nógrád & 6 & 83 & 11 & 5 & 81 & 14 \\
Észak & 13 & 65 & 22 & 12 & 61 & 27 \\
Magyarország & 20 & 60 & 20 & 20 & 56 & 24 \\
\hline
\end{tabular}

Forrás: Magyarország állatállománya 1991. március 31-én. KSHI Budapest 
Az adatok szerint a marhatartásban a nagyüzemek dominanciája érvényesül az 1991 . évi összeírások alapján. A Dunántúlon az országos átlagot meghaladja a vállalatok, gazdasági társaságok és szövetkezetek részesedése, míg az Alföldön és ÉszakMagyarországon az egyéni gazdaságok nagyobb aránya a jellemzö. Szembetúnỏ néhány megyében a kistermelés kiemelkedő részesedése, ezek: Szabolcs-Szatmár, Hajdú-Bihar, Borsod-Abaúj-Zemplén és Bács-Kiskun. Fel kell figyelni arra is, hogy az Alfơldön és az észak-magyarországi térségben lényegesen kisebb a vállalatok és gazdasági társaságok aránya, mint az országos átlag. Ugyanakkor főleg a Dunántúl néhány megyéjében (Komárom-Esztergom, Fejér, Tolna) a 30\%-ot is meghahaladja, a vállalatok és gazdasági társaságok részesedése, viszont ezen megyékben, Tolna kivételével $10 \%$ alatt van az egyénileg gazdálkodók hányada.

A szarvasmarha és tehénállományhoz hasonlóan, megyénként és tájanként elemeztük a sertés és kocalétszám 1991-95. években bekövetkezett változását, amelynek jellemző adatait a 8. táblázaton foglaltuk össze. Megállapítható, hogy a reprodukció alapját

\section{TÁBLÁZAT}

Az összes sertés és kocaállomány változása 1991-95. években, ezer egyed, illetve 1991. év indexében kifejezve\%

(Transition of the total number of pigs and sows in 1991-1995, in thousand and in per cent of the 1991 values)

\begin{tabular}{|l|c|c|c|c|c|c|}
\hline \multirow{2}{*}{ Megyék } & \multicolumn{3}{|c|}{ Összes sertés } & \multicolumn{3}{c|}{ Ebböl anyakoca } \\
\cline { 2 - 7 } & 1991 & 1995 & $\operatorname{lndex} \%$ & 1991 & 1995 & Index\% \\
\hline Baranya & 529 & 275 & 52 & 41 & 25 & 61 \\
Fejér & 437 & 284 & 65 & 34 & 24 & 71 \\
Györ-Moson-Sopron & 396 & 216 & 55 & 35 & 20 & 57 \\
Komárom-Esztergom & 256 & 202 & 79 & 19 & 16 & 84 \\
Somogy & 315 & 177 & 56 & 23 & 14 & 61 \\
Tolna & 496 & 267 & 54 & 35 & 22 & 63 \\
Vas & 190 & 104 & 55 & 12 & 7 & 58 \\
Veszprém & 233 & 161 & 69 & 17 & 11 & 65 \\
Zala & 159 & 89 & 56 & 8 & 5 & 63 \\
Dunántúl & 3011 & 1773 & 59 & 224 & 146 & 65 \\
Dél-Dunántúl & 1499 & 808 & 54 & 107 & 66 & 62 \\
Bács-Kiskun & 938 & 510 & 54 & 71 & 44 & 62 \\
Békés & 984 & 480 & 49 & 64 & 40 & 63 \\
Csongrád & 597 & 400 & 67 & 38 & 31 & 82 \\
Hajdú-Bihar & 808 & 459 & 57 & 57 & 41 & 72 \\
Jász-Nagykun-Szolnok & 688 & 329 & 48 & 50 & 30 & 60 \\
Pest, Budapest & 543 & 198 & 36 & 30 & 13 & 43 \\
Szabolcs-Szatmár-Bereg & 447 & 215 & 48 & 29 & 17 & 59 \\
Alfóld & 5005 & 2591 & 52 & 339 & 217 & 64 \\
Borsod-Abaúj-Zemplén & 296 & 156 & 53 & 17 & 11 & 65 \\
Heves & 186 & 100 & 54 & 12 & 7 & 58 \\
Nógrád & 90 & 49 & 54 & 4 & 2 & 50 \\
Észak & 572 & 305 & 53 & 33 & 20 & 61 \\
Magyarország & 8588 & 4669 & 54 & 596 & 383 & 64 \\
\hline
\end{tabular}

Forrás: Magyarország állatállománya 1991. március 31-én. KSH Budapest 1992. Állatállomány 1995, március 31. KSH Budapest 1995. 
jelentỏ kocaállomány csökkenése jóval kisebb, mint az összes sertésé. Ebböl az is következik, hogy a tenyésztök várakozó álláspontra helyezkedtek, vártak a recesszió elmúlására, a kedvezőbb közgazdasági környezetre, ami 1995. év második felében és 1996ban be is következett. A figyelmet arra is rá kell irányítani, hogy néhány megyében az összes sertés csökkenése jóval kisebb mértékủ, mint az országos átlag. E megyékben a húsipari biztos háttér sokirányú, de mindinkább az alapanyag-termelés integrálását előmozdító hatását kell kiemelni. Ez nyilvánul meg Csongrád megyében, ahol a PickSzalámi Gyár (Szeged), továbbá Veszprém megyében, amely a Pápai Húsipari Vállalat (Pápa), valamint Komárom-Esztergom megyében (Tata-Komárom) a Húsipari Vállalatok integráló szerepe jó irányban érzékelhető.

A húsipari vállalatok számára rendkivül nagy gondokat okoz a sertésállomány csökkenése. Az 1991-95. években, négy év elteltével csaknem 4 millióval (3,919 millió) esett vissza hazánkban a vágósertés-létszám, amely példátlan Európában, de talán az egész világon. Ugyanezen időszakban az Európai Unió számos országában emelkedett a sertések száma, Dániában például, ahol a Dunántúlnak megfelelő területen több mint 20 millió vágósertést állítottak elő, 18\%-kal növelték az állományt, hasonlóan Olaszországban, Spanyolországban, Portugáliában, Nagy-Britanniában, Svédországban, Ausztriában is. A világban is hasonló tendencia tapasztalható, az USA-ban 6\%-kal, Kínában 12\%-kal növelték a sertésállományt és 1994-ben Kína sertéstartó nagyhatalommá vált, 403 millió sertéssel. A volt „szocialista országokban” sem tapasztalható ilyen ,pusztitó erejü” állománycsökkenés, mint hazánkban, így például ugyanezen idöszakban Lengyelországban 2,6\%-kal, Ukrajnában 13\%-kal csökkent „csak” a sertésállomány, hazánkban viszont $46 \%$-kal.

\section{Az állatállomány csökkenésének gazdasági öszefüggései}

Az állatállomány változásának vizsgálata során az agrárközgazdasági szakirodalom kiterjedten alkalmazza az úgynevezett állatsưrủségi mutatók kiszámítását, amely a mezógazdasági terület és az állatlétszám kapcsolatát fejezi ki. Ennek során 100 ha mezõgazdasági területre (szántó, kert, gyümölcsös, szölö, gyep) vetítjük az összes szarvasmarha- és tehén-, valamint az összes sertés és kocalétszámot. llyen mutatószámokat ismertetünk a 9. táblázaton, amely megyénként és tájanként tartalmazza a szarvasmarha és sertésállomány, valamint a mezögazdasági terület kapcsolatát.

A szarvasmarha és tehénsürüség hazánk egészére jellemző mutatója nemzetközi öszszehasonlításban vizsgálva rendkivül kẹdvezötlen, számos hasonló adottságokkal rendelkezõ szomszédos és más európai országokban ennek többszöröse. ĺgy példảul a szarvasmarha-sürüség Dániába 78, Franciaországban 69, Angliában 65, Lengyelországban 41, a tehénsủrüség Dániában 27, Lengyelországban 21, Franciaországban 16, Angliában 15.

Az országra jellemzó átlagon belül az egyes tájak és megyék között lényeges eltérés tapasztalható.

A legnagyobb a szarvasmarha és tehénsürüség mutatója Györ-Moson-Sopron, illetve Vas és Veszprém megyében, a legkisebb Heves, Nógrád, Szabolcs-Szatmár-Bereg és Bács-Kiskun megyében.

Az állatállomány nagymértékü csökkenésének alapvető́en belsỏ gazdasági kényszerbỏl fakadó, de mégis szakágazati sajátosságokkal is jellemezhetỏ okai vannak. A gazdaságok nagy része ugyanis a tenyészállatok értékesitésével tudta csak fizetöképességét fenntartani, ezek árbevétele szolgált a munkabér kifizetések és járulékainak, továbbá 
föleg a rövidlejáratú forgóeszkōz-hitelek fedezésére. Ennek a sajảtos, az egész állattenyésztés hanyatlását elömozdító folyamatnak néhány ágazati sajátosságára külön is fontos a figyelmet felhívni:

a) Az állattenyésztés felszámolásával a baromfi és sertéságazatból nagyobb részt nem lehet a tőkét kivonni, egy megoldás maradt, folytatták a termelést, amíg a tárgyi eszközők állapota ezt lehetővé tette, s közben más célra fordították a képződött és elszámolt amortizációt.

b) A szarvasmarha- és juhtenyésztésben ágazati sajátosságaikból következően más a helyzet. Ezekben az ágazatokban az állatállomány és a takarmány jelentös összeget köt le, jóval meghaladja az összes lekötött vagyon értékének felét. A szarvasmarhaágazatokat felszámoló gazdaság egy tehénre vetítve 150-160 ezer Ft mobil pénzösszeghez jut ezáltal, így ugrásszerủen javíthatja likviditását. Emellett a szarvasmarhatenyésztés létesítményei, a telepek infrastruktúraja a leginkább felhasználható egyéb, jövedelmezőbb, kisebb kockázattal járó tevékenységre, bérbeadásra.

\section{TÁBLÁZAT}

Állatsürüségi mutatók 1995. március 31. 100 ha mezögazdasági területre jutó (Indices of the density of livestock per 100 hectare of agricultural land

on 31. March 1995)

\begin{tabular}{|l|c|c|c|c|}
\hline \multirow{2}{*}{ Megyék } & \multicolumn{2}{|c|}{ Szarvasmarha } & \multicolumn{2}{c|}{ Sertés } \\
\cline { 2 - 5 } & összes & ebböl tehén & öszzes & ebból anyakoca \\
\hline Baranya & 15 & 6 & 94 & 9 \\
Fejér & 19 & 8 & 87 & 8 \\
Györ-M-Sopron & 26 & 11 & 77 & 7 \\
Komárom-Esztergom & 13 & 5 & 132 & 11 \\
Somogy & 12 & 5 & 49 & 4 \\
Tolna & 18 & 7 & 98 & 8 \\
Vas & 26 & 11 & 50 & 3 \\
Veszprém & 21 & 9 & 64 & 4 \\
Zala & 15 & 7 & 39 & 2 \\
Dunántúl & 18 & 8 & 75 & 6 \\
Dél-Dunántúl & 15 & 6 & 70 & 6 \\
Bács-Kiskun & 10 & 5 & 83 & 7 \\
Békés & 13 & 5 & 100 & 8 \\
Csongrád & 16 & 7 & 116 & 9 \\
Hajdú-Bihar & 18 & 8 & 93 & 8 \\
Jász-Nagykun-Szolnok & 15 & 7 & 71 & 6 \\
Pest, Budapest & 13 & 6 & 46 & 3 \\
Szabolcs-Szatmár-Bereg & 10 & 5 & 47 & 4 \\
Alfóld & 13 & 6 & 79 & 7 \\
Borsod-Abaúj-Zemplén & 10 & 5 & 34 & 2 \\
Heves & 9 & 4 & 43 & 3 \\
Nógrád & 10 & 6 & 34 & 1 \\
Észak & 10 & 5 & 37 & 2 \\
Magyarország & 15 & 7 & 72 & 6 \\
\hline
\end{tabular}


c) A kedvező tenyészüsző árak szinte ösztönöznek az értékesítésre. 1995-96. években egy elörehaladott vemhességủ tenyészüszöért elérhetö 175-180 ezer Ft a hazai és külpiacon, amely a szorító gazdasági helyzetben azonnali likvid pénzt jelent. Az elözöekből következik, hogy a különböző gazdasági szervezetek, a nöivarú állományokat, tenyészértéküket figyelmen kívül hagyva, vemhesítik, majd export útján értékesítik. Ez a gyakorlat a következő káros gazdasági konzekvenciákkal jár:

- a selejtezésre kerülỏ tehenek utánpótlása elmarad, így csökken a tehénállomány és ennek következtében visszaesik a kibocsátás (tej és borjú);

- a selejtezésre érett, kiöregedett teheneket továbbra is termelésben tartják, amely hozamcsőkkenést és hatékonyság romlást okoz.

d) A belföldi élöállatforgalomban kialakult torz és irreális értékrendek, felhajtott árak közvetett módon állománycsökkenést involválnak. Ez összefüggésben van azzal, hogy az Európai Unió agrárrendtartása lehetóvé teszi tagországainak azt, hogy a $300 \mathrm{~kg}$ élötömegnél kisebb, föleg húshasznú (chorolais, limusin, hereford és hústípusú magyartarka) állományokat hízóalapanyagként diszkrimináció (védővám, lefölözés) nélkủl importáljanak. Az olasz piac részéről megnyilvánuló nagy kereslet olyan belső árfelhajtó hatással járt, hogy 1995-96. években egy 280-300 kg élötömegú húshasznú növendék állatért 100 ezer Ft körüli árbevétel (300-320 Ft/élötömeg kg) is elérhetö. Itt a gondokat fokozza és az állománycsökkenéshez hozzájárul az is, hogy a hízóalapanyagként exportált állományok között továbbtenyésztésre alkalmas üszők is vannak.

\section{THE REGIONAL FEATURES OF ANIMAL HUSBANDRY IN HUNGARY}

\section{GYULA SZÉLES}

In the years of 1990-1995 both the volume and the share of the foreign currency incomes declined as a consequence of the significant decrease in the number of the livestock. The unfavourable developments in the export mainly struck the meat processing industry, which could be seen in the decline of the export of both pigs and cattle and of pork and beef. This brought about several economic consequences, from which the following should be emphasised: Meat processing industry is one of the leading sectors of the Hungarian agricultural economy, thus its development takes a significant sacrifice from the national economy, on the other hand, the decreasing number of livestock brings about problems of the capacity utilisation, which, because of the increase in fixed costs, further worsens the international competitiveness of the Hungarian agricultural products.

The essay analyses in details the regional features of the changes in the number cattle, within this cows, also the total number of pigs, with special regard to sows, in the period 1991-1995. It emphasises that the decrease in the number of cattle and cows shows differences among the regions and it concerns regions where the ecological and economic conditions for keeping cattle are much more favourable than the national average. The analyses covers the breakdown of the cattle and cow stock by economic organisations, where the author uses the following categories: Firms and economic companies, co-operatives and private smallholders. The data show significant regional differences here, as well. The study provides a detailed analysis of the regional features of the de- 
velopment of the number of pigs and sows in the years of 1991-1995. It emphasises that in this respect there are smaller differences compared to the national average. It also points to the fact that in the number of pig-stock, in some regions the integrating activities of the meat processing companies can be palpable. The essay underlines that the volume of the decrease in the number of livestock that took place in Hungary is unique in the world economy and even in Eastern and Central Europe.

Finally, the author analyses in details the factors which in his opinion are dominant for the large decline of the livestock. Within the economic factors, he gives a special emphasis to the strong pressure caused by financial and liquidation issues.

Translated by Zoltán Raffay

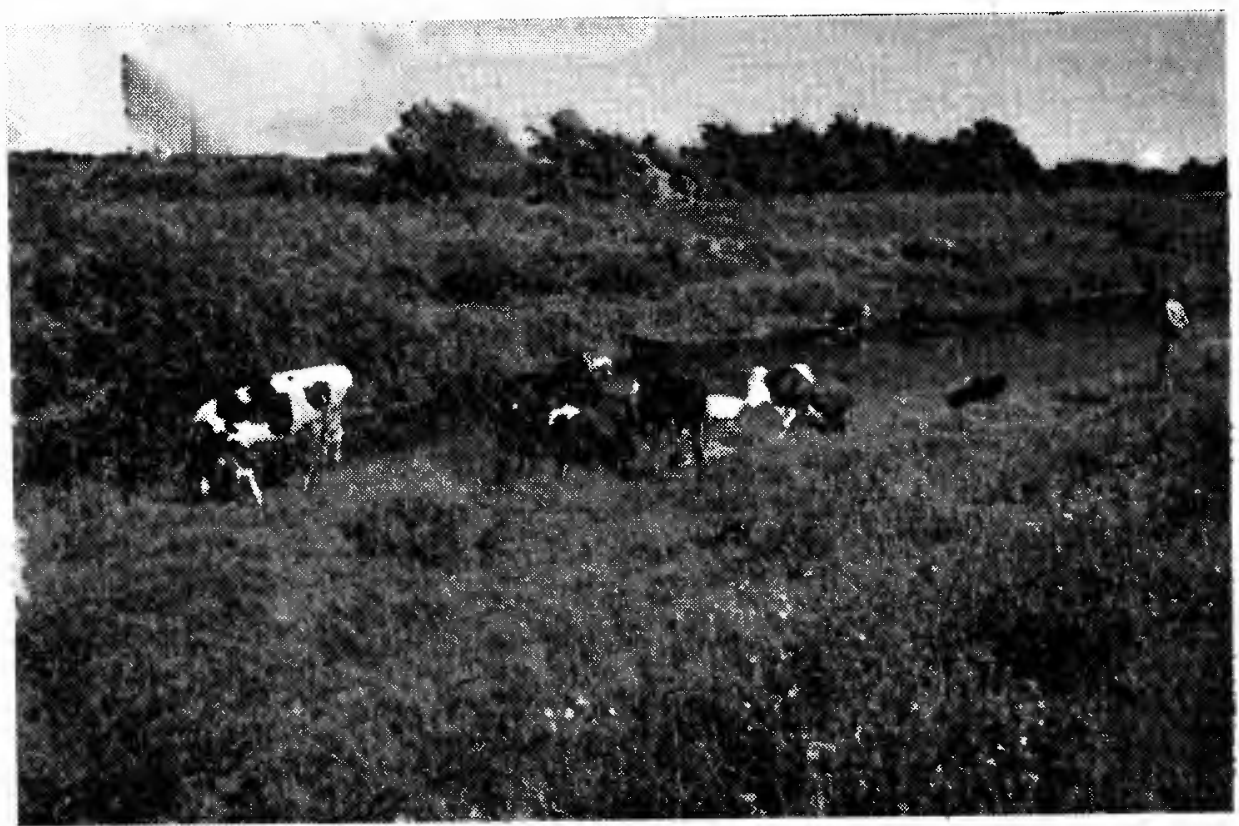


Régiók felemelkedése és hanyatlása. Regionális fejlödés és politika a Brit-szigeteken. Szerk: Horváth Gy. Pécs; MTA Regionális Kutatások Központja, 1997. kb. 500 p. (Régiók Európája, ISSN 12174882; 2) ISBN 96385409 07. Ara: $2300 \mathrm{Ft}$.

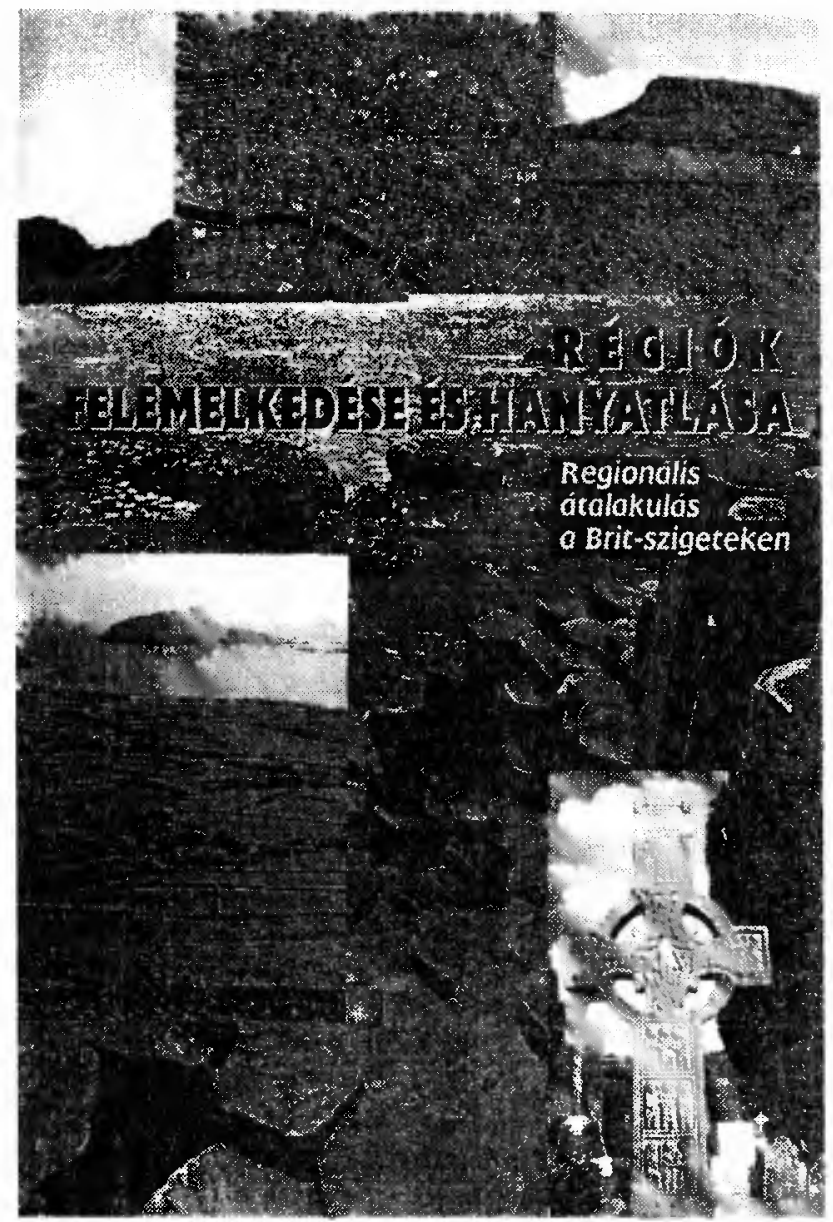

Az MTA Regionális Kutatások Központjának Régiók Európája c. könyvsorozata az európai regionális fejlödés sajátosságait, a településrendszerek, közigazgatási egységek és gazdasági ágazatok kölcsönhatásait, a regionális fejlesztés és intézményeinek funkcióit mutatja be. A sorozat első kötete az olasz regionalizmus mozgató erỏit èlemezte.

A sorozat 2. kötete 1997-ben jelenik meg „Régiók felemelkedése és hanyłatlása. Regionális fejlôdés és politika a Brit-szigeteken" címmel. A kötet az Egyesült Királyság és Îrország területi fejlódésének, a regionális átalakulás befolyásoló tényezöinek, a regionális politika eszközeinek különböző kérdéseit vizsgálja. Az ír és brit szakemberek munkáiból összeállított kötet bevẹzető tanulmányát a sorozat szerkesztője, Horváth Gyula írta.

Az 1997. II. negyedévében megjelenó könyv az MTA RKK könyvtárában (7601 Pécs, Pf. 199) rendelhető meg. 